\title{
The Nature of Stakeholder Satisfaction with Marketing Education
}

\author{
Steven A. Taylor ${ }^{1} \&$ Kim Judson ${ }^{1}$ \\ ${ }^{1}$ Department of Marketing, Illinois State University, Normal, USA \\ Correspondence: Kim Judson, Department of Marketing, Illinois State University, Normal, IL, 618790-5590, \\ USA. Tel: 1-309-438-2715. E-mail: kmjuds2@ilstu.edu.
}

Received: May 13, 2014 Accepted: July 1, 2014 Online Published: July 30, 2014

doi:10.5539/hes.v4n4p89 URL: http://dx.doi.org/10.5539/hes.v4n4p89

\begin{abstract}
The current article represents a cautionary tale in continuing emerging marketization practices as the dominant form of marketing with higher education. Specifically, a review of three important emerging literature streams (i.e., quality-of-life, service-dominant logic, and stakeholder orientation) all appear to support calls for moving beyond typical (short-term, hedonistic) measures of consumer satisfaction associated with the delivery of higher education toward satisfaction judgments based on higher-order forms of happiness (i.e., prudential and perfectionist forms of happiness such as eudaimonia). This conclusion suggests that the nature of long-term value co-creation associated with higher education should focus on quality of life and well-being. Critical to the success of moving marketing strategy of institutions of higher education in the direction asserted herein will be embracing a primary strategic marketing objective of convincing stakeholders to value long-term, eudaimonic forms of happiness and satisfaction over the current psychological, short-term, hedonistic satisfaction forms assessing today's marketization practices. A series of propositions are offered to help guide marketers in embracing this perspective.
\end{abstract}

Keywords: marketization, higher education, quality-of-life, service-dominant logic, stakeholder orientation

\section{Introduction}

\subsection{Eudaimonic Forms of Stakeholder Satisfaction in Higher Education}

Judson and Taylor (2014) distinguish today's typical marketing practices in higher education as marketization (i.e., short-term demand oriented based on delivered value) from marketing practices that are long-term and relationship based on co-created value. These authors further discuss how consumer-forms of stakeholder satisfaction have become the primary measures of marketing "success" with higher education. The current paper considers potential public policy implications of continued reliance on stakeholder satisfaction judgments as the primary measure of "success" in the marketing of higher education. When one considers the nomological net of value-related concepts in consumption suggesting that stakeholder satisfaction partially mediates the relationships between both quality perceptions, consumption value and cost-based value, consumption value (Oliver 1999), then the importance of long- versus short-term stakeholder satisfaction becomes apparent.

This article specifically evaluates Judson and Taylor (2014)'s normative call for framing marketing performance as eudaimonic forms of happiness and stakeholder satisfaction within the context of higher education. We evaluate their call through the lenses of the emerging (1) stakeholder marketing literature (Bhattacharya 2010), (2) Service Dominant Logic (SDL, Vargo and Lusch 2004) theory of marketing, as well as (3) Sirgy's (2012b) argument that public policy should be informed and guided, at least in part, by happiness research-in particular, the emerging quality of life (QOL) literature. The results suggest that all three emerging literature streams generally support calls to move the marketing of higher education away from today's prominent marketization emphases.

The remainder of this article is divided into several sections. First, the emerging QOL literature is reviewed to help identify and distinguish the alternative forms of happiness upon which satisfaction measures can be based as measures of marketing performance. This review suggests that psychological/hedonistic forms of happiness appear most closely related to the short-term orientations often associated with value delivery within today's typical marketization practices. However, the QOL literature appears to instead largely advocate an emphasis on long-term prudential and perfectionist forms of happiness consistent with the eudaimonic perspective advocated by Judson and Taylor (2014). Second, the emerging SDL perspective of marketing vis-à-vis the marketing of 
higher education is summarized suggesting that eudaimonic forms of happiness/satisfaction appear more appropriate than hedonistic measures as measures of long-term value co-creation as associated with emerging marketing theory and practice. Third, the emerging stakeholder marketing literature is reviewed to identify the most appropriate conceptualization of stakeholder orientation to drive marketing strategies in the marketing of higher education. The results of this analysis also appear more consistent with a longer term perspective than is associated with today's typical marketization practices. Finally, a series of propositions are included to help support movement toward more expansive, longer-term constitutive and operational definitions of "satisfaction" as a desired outcome of the delivery of higher education as a service product.

\subsection{What Alternative Forms of Satisfaction Are Available to Assess Marketing Performance with Higher Education?}

Why is stakeholder satisfaction so prominently used as a measure of marketing performance? Oliver (2012) touches on this issue by noting that the term "satisfaction" is commonly considered as a lay synonym for other summary cognitive/affective summary terms like "happy" and "pleased." Oliver (2012) further distinguishes various stakeholder perspectives from which to derive satisfaction judgments, including consumer, firm, industry, and societal perspectives. Oliver's influential work tends to focus on the consumer's perspective, which emphasizes goal-related, individual pursuits in the consumption of services. Not surprisingly, we demonstrate below that the consumers' perceptions of satisfaction dominate marketization practices in higher education, which we will further argue unfortunately present a conflict between the individual's goals and societal education goals. Universities are caught in the middle of this conflict. Importantly, we are not advocating movement away from measurement of stakeholder happiness/satisfaction as an important measure of marketing success in higher education. Rather, we are taking exception to consumerist (i.e., hedonistic, short-term, job-training oriented) theoretical and philosophical foundations of satisfaction judgments underlying today's marketization emphasis as the primary basis for defining "marketing success" in higher education marketing strategies.

\subsection{Satisfaction}

Oliver (2012, p. 8) defines the concept of satisfaction as “...the consumer's fulfillment response. It is a judgment that a product/service feature, or the product or service itself, provided (or is providing) a pleasurable (italics not added) level of consumption-related fulfillment, including levels of under- and over-fulfillment." Oliver (2012) continues by suggesting that (1) satisfaction is a summary state of a psychological process, (2) the processes leading to the satisfaction response are essentially isomorphic (i.e., similar across domains and settings), (3) includes both affective and cognitive components of judgment, (4) that these processes must include (goal-related) standards (e.g., expectations), and (5) satisfaction as a consumption response cannot occur without such a comparison standard. As noted above, given that the consumer satisfaction response has a significant affective component, Oliver notes that terms like happy and pleased are frequently used to tap satisfaction feelings (Note 1). Judson and Taylor (2014) assert that today's typical stakeholder evaluations include perceptual (short-term, goal-related) measures of pleasure in the consumption of higher education delivery. Oliver (2012) argues that satisfaction-as-pleasure is a form of reinforcement satisfaction that reflects the difference between positive reinforcement (i.e., inducing or increasing a pleasurable state) and negative reinforcement (reducing or eliminating an unpleasant state). Thus, satisfaction is arguably typically seen as an affectively-related motivator of human behavior related to the goal-relevant consumption of higher education. Judson and Taylor (2014) observe that satisfaction-as-pleasure underlies many of the stakeholder evaluations commonly used today (e.g., student, employer, etc.). These evaluations are then increasingly being used to assess faculty and organizational performance in higher education. We demonstrate below that what results is a largely hedonistic stakeholder perspective increasingly reinforcing an emphasis on marketization practices, with a consequent short-term, demand-oriented orientation toward marketing success. This article represents a cautionary tale in continuing too far down the road of hedonistic forms of stakeholder satisfaction as primary measures of success in the marketing of higher education.

\subsection{The Quality of Life (QOL) Literature -The Alternative Forms of Happiness \& Satisfaction}

The processes leading to satisfaction judgments can vary in important ways. We assert herein that the emerging QOL, happiness, and positive emotions domains of inquiry appear particularly well suited to help identify the foundations of the various potential forms of satisfaction judgments. The basic interest underlying these emerging literatures involves the appropriate, and therefore desired, outcome (or dependent variable) of models directed toward goal-related outcomes (like QOL). Myers and Deiner (1996) identify the emergence of "happiness" research as a means to better understand happiness and satisfaction with various aspects of their 
lives - with "subjective well-being" initially representative of global evaluations of these judgments. Fave (2013) further argues that "happiness" is increasingly gaining momentum as a (1) general core topic of social science research, and (2) specifically as a goal for individuals and societies. Sirgy (2012b, p. 1) argues that “ $\ldots$ there are a plethora of concepts commonly associated with the subjective aspects of QOL, subjective well-being, life satisfaction, domain satisfaction, positive/negative affect, emotional well-being, hedonic well-being, prudential happiness, flourishing, positive mental health, psychological happiness, perfectionist happiness, the good life, among others." We argue that appropriately distinguishing concepts such as happiness and QOL from the many very similar and related concepts is a useful starting place to begin to better understand the most appropriate forms of stakeholder satisfaction to assess faculty and organizational performance associated with institutions of higher learning's marketing success.

Table 1. Three philosophical concepts of happiness (Adapted from Sirgy 2012a)

\begin{tabular}{ll}
\hline \multicolumn{1}{c}{ Concept } & \multicolumn{1}{c}{ Constitutive Definition } \\
\hline & The experience of positive \\
Psychological & $\begin{array}{l}\text { emotions over time } \\
\text { Happiness } \\
\text { resulting in a state of mind } \\
\text { indicates the } \\
\text { pleasant life) }\end{array}$ \\
& $\begin{array}{l}\text { involving feelings of joy, } \\
\text { (Haybron 2000). Indicates }\end{array}$ \\
& the pleasant life.
\end{tabular}

Refers to a state of well-being. Is accomplished when a person achieves a

Prudential

Happiness (attitude; indicates the engaged life) high state of well-being, both mentally and physically. Involves both feelings of happiness and the action that generates personal growth. Indicates the engaged life.

Refers to a life being good Perfectionist in all respects; including a Happiness moral life. Thus, this is (purpose; indicates the achieves a state of meaningful life) leading a moral life. Indicates the meaningful life.

A Scale Capturing All Three Forms
As life satisfaction (Diener et al. 1985a, 1985b); as domain satisfaction (Yiengprugsawan et al. 2010); as flow and engagement (Csikszentmihalyi 1997); as desire satisfaction (McGill 1967); as attitudinal pleasure (Feldman 2010);

As positive and negative affect (Diener et al. 2010); as hedonic sensations and momentary pleasures (Dockray et al. 2010); as neural chemical release of dopamine in the brain; as psychological happiness in the form of utility; as emotional well-being (Simsek 2009);

Focuses on subjective well-being (SWB) in the form of somewhat longer term goal gratification and longer-term (summative) hedonistic approach. Psychological happiness may be necessary but not sufficient to achieve prudential happiness (Kesebir and Diener 2009).

As eudaimonia (Abbott et al. 2010; It is a life that is Diener et al. 2010); as purpose and desirable without meaning in life (Steger et al. 2006); qualification, both as positive mental health or enviable and admirable. flourishing (Keyes 2002); as Focuses on subjective satisfaction of the full spectrum of well-being (SWB). Most human basic and growth needs closely related to the (Sirgy et al. 1995); ) eudaimonic approach.

Orientation to Happiness Scale (Chen 2010).

Sirgy (2012a) argues that happiness (1) is both a philosophical and psychological construct, and (2) serves as a 
strong and universal (goal-related) motive in human judgment and decision-making (J/DM). Sirgy (2012a) summarizes the extant literature and identifies three unique philosophical concepts of happiness (see Table 1). Sirgy (2012a) first identifies objective versus subjective forms of happiness, describing the former as assuming that well-being can be described through behaviors and activities that contribute to shape the good life in accordance with shared values, moral principles, and universal features of human nature, with the latter perspective identifying happiness with the fulfillment of subjectively perceived desires and aspirations. These alternative perspectives have led to the identification of two different but complementary perspectives of individual well-being, including (1) hedonism, which is centered on the concept of subjective well-being (SWB) -- including positive and negative affect and global life satisfaction judgments, versus (2) eudaimonic approach, focusing on the fulfillment of one's true nature (including self-actualization and commitment to socially shared goals). Sirgy (2012a), p. 5) states that "One of the basic differences between these two perspectives is that the eudaimonic approach focuses on the process of living well, investigating the factors that contribute to it; the hedonic approach is instead prominently focused on the outcomes of this process." Phillips (2006) further argues that the hedonic tradition emphasizes the individual and assumes that people are motivated to enhance personal freedom, self-preservation, and self-enhancement - i.e., the focus is on the integrity of the individual and his/her own judgment as to what makes them happy. Eudaimonic traditions derive from Aristotelian concepts of the good life, prudence, reason, and justice - i.e., the goal is to have people flourish toward their full potential, to contribute to society, and to achieve the highest standards of morality. This leads to the first proposition:

P1: Marketers interested in using stakeholder happiness/satisfaction measures of marketing "success" should recognize (1) the philosophical/theoretical/constitutive differences between psychological, prudential, and perfectionist forms of happiness (see Table 1), and (2) seek to identify the appropriate relative mix of these different forms of happiness reflected in conceptualizations and operationalizations of stakeholder satisfaction in their own institutions of higher learning.

\subsection{Millennial Students and Employer Stakeholders Tend to Focus on Perceived Job Relevancy and Their Own (Short-Term) Goal Gratification in Making Perceived Value Judgments}

These differences in forms of happiness promise to be significant when considered from the almost universally agreed upon importance of the stakeholder happiness/satisfaction in consuming higher education. Judson and Taylor (2014) identify the goal-related nature of happiness/satisfaction judgments psychologically. Taylor et al (2011a) conduct qualitative goal-mapping of business undergraduate students and present results strongly supporting the conclusion that students tend to focus on utilitarian, attribute-level considerations mainly related to credentialing for purposes of employment. These results appear consistent with the meta-analytic findings of Twenge et al. (2012) who present evidence that (when compared to Baby Boomers at the same age) Millennials as a group (1) consider goals related to extrinsic value (money, image, fame) more important that those related to intrinsic value (self-acceptance, affiliation, community); demonstrate declining concern for (2) others, and (3) civic orientation. They characterize Millennials (as today's typical undergraduate student) as "Generation Me" versus previous generations being better characterized as "we-oriented." Stein (2013) similarly characterizes Millennials as increasingly narcissistic and focused on their own short-term goals.

The point of this is not to disparage Millennials generally, rather, to better understand how this generation of student forms conclusions about perceived value. If consumption-based perceived value largely reflects conclusions based on perceptions of "Get/Give Up" as demonstrated by Zeithaml (1988), then student perceptions of value through goal-achievement are going to be positively related to (1) perceptions of relevancy of education vis-à-vis employment and shorter-term pleasurable outcomes (e.g., positive reinforcement, building self-esteem, grades) in the numerator, and (2) reductions in time effort, and dollars necessary to achieve credentialing through education in terms of the denominator. Given this observation, the growing reliance of institutions of higher learning having to maintain enrollments through marketing/sales (i.e., marketization) and toward marketization-based measures of success (e.g., short-term, hedonistic stakeholder satisfaction) is not at all surprising (see Judson and Taylor 2014). This leads to the next five propositions:

P2: Perceptions of value in the consumption of higher education are most heavily influenced by perceived job relevancy and one's own short-term goal gratification.

P3: Today's typical measures of perceived stakeholder marketing "success" are largely related to marketization-based measures of marketing performance (e.g., course evaluations, student/employer satisfaction, student engagement, intended positive word-of-mouth behaviors, obvious linkages to post-graduation jobs, etc.) which are most closely related to psychological happiness, and hedonistic forms of SWB. 
P4: Today's typical organizational measures of marketization success in higher education (e.g., course evaluations, student/employer satisfaction, student engagement, intended positive word-of-mouth behaviors, obvious linkages to post-graduation jobs, etc.) appear most closely related to psychological happiness, and hedonistic forms of SWB.

P5: Other goals of higher-education organizations such as life-long learning, breadth of education, critical thinking, and personal knowledge/growth appear more closely related to perfectionist happiness, and eaudaimonic forms of SWB.

P6: Measures of life-long learning, breadth of education, critical thinking, and personal knowledge/growth appear largely unrelated to Millennials' perceptions of perceived value with higher education.

Table 2. Inner versus outer aspects of well-being (Adapted from Veenhoven 2000 and Sirgy 2012b)

\section{Outer Well-Being}

(How the Environment Supports Personal Well-Being)

\section{Inner Well-Being}

(Personal Ability to Live a Fulfilling Life)

\section{Quality of conditions external to the} individual. Examples:

- The quality of the educational product.

- The quality of the environment in which the educational product is delivered.

(Opportunities for Good Life)

\section{Outcome Well-Being}

(The Good Life Itself)
- The quality off stakeholder human support systems.

- The economy.

- Government support of education.

Utility of life; Personal contribution to the good life; Moral character of the individual. Examples:

- Sustainability-oriented acts

- Community service
- Acts of charity/philanthropy
The ultimate dependent variable for social psychology studies of students and other stakeholders. Examples:

- Life satisfaction

- Happiness

- $\quad$ Perceived QOL

- Various forms of well-being

1.6 The Normative Argument from the QOL Literature for Focusing on Prudential and Perfectionist Forms of Happiness as the Basis for Measures of Long-Term Marketing "Success" in Higher Education

These theoretical propositions have implications in terms of using stakeholder satisfaction measures as operationalizations of "marketing success" in higher education. Sirgy (2012b) further discusses the issue of objective versus subjective measures of QOL indicators by building on Sumner's (1996) basic definitions of objective indicators of QOL as requiring a point of view independent from the individuals whose QOL is being 
assessed, versus subjective indicators tapping into the individual's whose well-being reflects the individual's state of mind (e.g., values, attitudes, beliefs, motives, personality, emotional state, etc.). Sirgy (2012b) calls for categorizing well-being into a matrix of Inputs/Outcomes versus Outer/Inner well-being (see Table 2). Sirgy (2012b) identifies inner well-being as characterized in terms of input conditions such as the ability to live a fulfilling life, whereas outer well-being can be characterized in terms of the livability of the environment. While ultimately calling for public policy based on both subjective and objective measures of QOL, Sirgy (2012b) further suggests that the inner conditions of well-being should serve as the ultimate dependent variable in analytical studies as all other conditions of well-being arguably are determinants or antecedent conditions to inner well-being. Thus, Sirgy (2012b) suggests dependent variables in studies of the social psychology of QOL should focus on explaining longer-term outcome/inner well-being in terms of life satisfaction, happiness, perceived QOL, absence of ill-being, positive affect, eudaimonia, subjective well-being, psychological well-being, etc. Table 2 adapts Sirgy's (2012b) adaptation of Veenhoven's (2000) distinctions within the context of the marketing of education. This leads to the seventh and eighth propositions:

P7: The dependent variables in studies of the social psychology of higher education consumption should focus on explaining long-term well-being in terms of life satisfaction, happiness, perceived QOL, absence of ill-being, positive affect, eudaimonia, subjective well-being, psychological well-being, etc.

P8: Measurement of marketing "success" associated with higher education from a QOL perspective calls for a focus on inner well-being, which appears more closely aligned with prudential and perfectionist forms of happiness (philosophically).

The foundation formed in Tables $1 \& 2$ above contribute to clarifying how to treat Outcome/Inner Well-Being as portrayed in Table 2 vis-à-vis the delivery of higher education. Sirgy (2012b) and argues that the literature supports the conclusions that (1) happiness and life satisfaction are two different constructs, (2) satisfaction is derived from goal attainment, and (3) life satisfaction favors cognitive processes whereas happiness favors affective influences. Sirgy (2012b, pp. 36-37) proposes treating subjective well-being (SWB) as an umbrella concept for this purpose, defined as:

"Subjective well-being is an enduring (long-term) affective state that is made of a composite of three components: (a) actual experience or happiness or cumulative positive affect (joy, affection, pride, etc.) in salient life domains, (b) actual experience of depression of cumulative negative affect (sadness, anger, guilt, shame, anxiety, etc.) in salient life domains, and (c) evaluations of one's overall life or evaluations of salient life domains."

Thus, from this perspective, SWB as a construct has three dimensions: (1) cognitive versus affective influences, (2) positive versus negative affective influences, and (3) short-term versus long-term (i.e., transient versus enduring affective states). At a minimum, we suggest that measures of success in marketing higher education should capture both short-term and long-term measures of SWB based on this discussion. This leads to the ninth proposition:

P9: At a minimum, we suggest that perceptual QOL-related measures of success in the successful marketing of higher education should capture all three identifiable dimensions of SWB (i.e., cognitive/affective, positive/negative, and short- versus long-term).

Table 3. Hedonia versus eudaimonia (Adapted from Vitterso et al. 2010)

\begin{tabular}{|c|c|c|}
\hline & Hedonia & Eudaimonia \\
\hline \multirow{4}{*}{$\begin{array}{l}\text { Feeling } \\
\text { State }\end{array}$} & $\begin{array}{l}\text { - Is a feeling state reflecting } \\
\text { happiness. }\end{array}$ & $\begin{array}{l}\text { Is a feeling state reflecting interest } \\
\text { and related to equilibrium. }\end{array}$ \\
\hline & - Serves an adaptive role to regulate & - Serves to regulate change and growth. \\
\hline & $\begin{array}{l}\text { homeostatis and equilibrium in } \\
\text { human systems. } \\
\text { - Satisfaction is very closely related to }\end{array}$ & $\begin{array}{l}\text { - Interest arises from slight disruptions } \\
\text { from equilibrium. }\end{array}$ \\
\hline & & - Satisfaction is a poor predictor of \\
\hline
\end{tabular}


hedonic feelings.

- Goal achievement represents a return to equilibrium in individuals.

- $\quad$ Pleasure is the feeling created when goals are achieved.

- Pleasure creates motivation.

- Is trait like, reflecting a lasting and consistent concern for judging the output of an action along the dimensions of good and bad.

- The general orientation toward goodness and badness of a situation

Orientation is captured by commonly used life satisfaction measures.

- Serves to moderate the relationship between equilibrium/assimilation $\rightarrow$ hedonic feelings in typically pleasant and easy (less challenging) environments. eudaimonic feelings.

- The expectation of pleasure is experienced in the process of goal achievement.

- Engagement and interest generate and sustain curiosity, even for intellectual pursuits.

- Interest creates motivation.

- The term personal growth represents the trait-like aspect of eudaimonic well-being.

- Reflects an individual tendency for valuing efforts and challenges, to be oriented toward processes rather than outcomes and to pay attention to aspects in the circumstances with a potential for skill improvement.

- $\quad$ Serves to moderate the relationship between the slight disturbance of equilibrium $\rightarrow$ eudaimonic feelings in challenging environments.

Table 3 presents a summary of Vitterso et al.'s (2010) distinctions between hedonia and eudaimonia, and how they relate herein. The concept of hedonic well-being (HWB) refers to a single dimension of evaluations in terms of goodness and badness (Kahneman, 1999, Vitterso et al., 2010). Consistent with Oliver's (2012) arguments, Vitterso et al. (2010) assert that a number of studies have demonstrated that humans tend to use terms such as good, pleasant, happy, and satisfactory relatively interchangeably, suggesting that HWB is used as an umbrella term for subjective experiences and evaluations that are bipolar opposites . (e.g., satisfied - dissatisfied). Alternatively, Vitterso et al. (2010) state that HWB does not capture the complete range of positive emotions in a fully functioning person, and that satisfaction is a poor predictor of eudaimonic feelings that does not appear capable of accounting for the experiential states that accompany the persistent striving toward challenging goals. This leads to the tenth proposition:

P10: The concept of satisfaction when based solely upon HWB is a poor predictor of eudaimonic judgments and feelings (e.g., satisfaction) associated with success in the marketing.

It is worth noting that Kesebir and Diener (2009) assert that SWB and eudaimonic happiness are not interchangeable concepts because it is easy to imagine a person who feels subjectively happy without leading a virtuous life. Sanjun (2011) asserts that SWB is multidimensional in nature, including both hedonic and eudaimonic aspects. Hedonic well-being focuses on happiness, whereas eudaimonic well-being focuses on developing human potential. Sanjun (2011) presents empirical evidence that the components between psychological well-being and subjective well-being are strongly interrelated, with mediational analyses demonstrating that affect balance mediates the relationship between some positive life attitudes and satisfaction with life. Raibly (2013) further demonstrates that happiness and well-being are conceptually, metaphysically, and empirically distinct concepts. He first differentiates happiness as episodic feelings or experiences of happiness from happy as an emotional condition. Specifically, happiness in terms of emotional conditions are broadly positive, involving stances of attunement, engagement, and endorsement (Note 2), with only a minor extent of negative central affective states and mood propensities. An alternative interpretation involves (1) emotions and feelings, which include joy, temporary happiness, cheerfulness, being merry, euphoria, and moments of pleasure, versus (2) harmony and balance, which include feelings of inner peace, positive relations with oneself, contentment, and serenity. He then argues that a particular theory of well-being 
(as agential flourishing) offers a good explanation of when and why episodic happiness and happiness in the personal attribute sense are directly beneficial. This theory states that an adult human is doing well at a time to the degree to which they resemble a person who successfully realizes their values and is stably disposed to do so. This person must have values, must desire to realize these values, and must possess a mind and body suitable for action on behalf of these values. Further, this person must actually pursue and realize these values through their own efforts - and experience appropriate emotional feedback on this entire system, Thus, a flourishing agent's valuational and motivational systems function fruitfully and harmoniously in this view. Harm or benefit, in this view is proportional to the degree to which a person moves closer or further away from this state. Raibly (2013) further argues that his theory also explains why pursuit and achievement of goals, mental health, and feelings of personal expressiveness are intimately connected with well-being and happiness, consistent with eudaimonic traditions of psychology.

This leads to the eleventh and twelvth propositions:

P11: Raibly's (2013) theory of well-being as agential flourishing can be generalized to the marketing of higher education as a basis for eudaimonic performance standards.

P12: Raibly's (2013) theory of well-being as agential flourishing provides a reasonable theoretical underpinning for models of "success" in the delivery of properly marketed higher education from a QOL perspective.

Sirgy (2012b) suggests that educational well-being is proxied by student well-being which are typically tied to satisfaction with academic and social aspects of the college experience. Further, quality of college life has been conceptualized as the degree of need satisfaction and the experiences that create a positive affect throughout college life. In short, the concept of satisfaction is intimately related to college student well-being and the quality of their college experience. Leon and Nunez (2013) investigate the relationship between well-being and satisfaction of basic psychological needs perspective in an educational setting. These authors report evidence supporting the causal ordering of competence and relatedness on well-being consistent with self-determination theory. They ultimately call on universities to promote relations between students and support the need of competence. This leads to the thirteenth proposition:

P13: The concept of satisfaction vis-à-vis flourishing (i.e., eudaimonia) is intimately related to college student well-being and the quality of their college experience, and should serve as a measure of perceived stakeholder marketing "success" in the marketing of higher education.

Table 4. Satisfaction as hedonia versus eudaimonia

\begin{tabular}{|c|c|c|}
\hline & Satisfaction as Hedonia & Satisfaction as Eudaimonia \\
\hline $\begin{array}{l}\text { Relationship to } \\
\text { Marketing Views of } \\
\text { Value }\end{array}$ & $\begin{array}{l}\text { Focuses on immediate gratification of value delivery, } \\
\text { consistent with marketization orientation. }\end{array}$ & $\begin{array}{l}\text { Focuses on co-creation of value, } \\
\text { consistent with SDL-based } \\
\text { marketing orientation. }\end{array}$ \\
\hline $\begin{array}{l}\text { Consistency with } \\
\text { Philosophical } \\
\text { Views of Happiness }\end{array}$ & $\begin{array}{l}\text { Focuses on psychological happiness, indicating the } \\
\text { pleasant life. }\end{array}$ & $\begin{array}{l}\text { Focuses on perfectionist } \\
\text { happiness, indicating the } \\
\text { meaningful life. }\end{array}$ \\
\hline $\begin{array}{l}\text { Consistency } \\
\text { Aspects } \\
\text { Well-Being }\end{array}$ & Focuses on Outer/Input Well-Being & $\begin{array}{l}\text { Focuses on Inner/Outcome } \\
\text { Well-Being }\end{array}$ \\
\hline $\begin{array}{l}\text { Temporal } \\
\text { Orientation }\end{array}$ & Short-term & Long-term \\
\hline $\begin{array}{l}\text { Basis } \\
\text { Perceptual } \\
\text { Judgment }\end{array}$ & Perceived utility in short-term goal achievement & $\begin{array}{l}\text { Perceived personal growth in } \\
\text { terms of long-term goal } \\
\text { achievement }\end{array}$ \\
\hline $\begin{array}{l}\text { Typical Attributes } \\
\text { Measured for } \\
\text { Marketing }\end{array}$ & $\begin{array}{l}\text { External university rankings, student enrollment } \\
\text { trends, student course evaluations, work-force } \\
\text { training } \quad \text { efficacy } \quad \text { (i.e., perceived job }\end{array}$ & $\begin{array}{l}\text { Life-long learning, personal } \\
\text { growth and development, critical } \\
\text { thinking acumen, }\end{array}$ \\
\hline
\end{tabular}




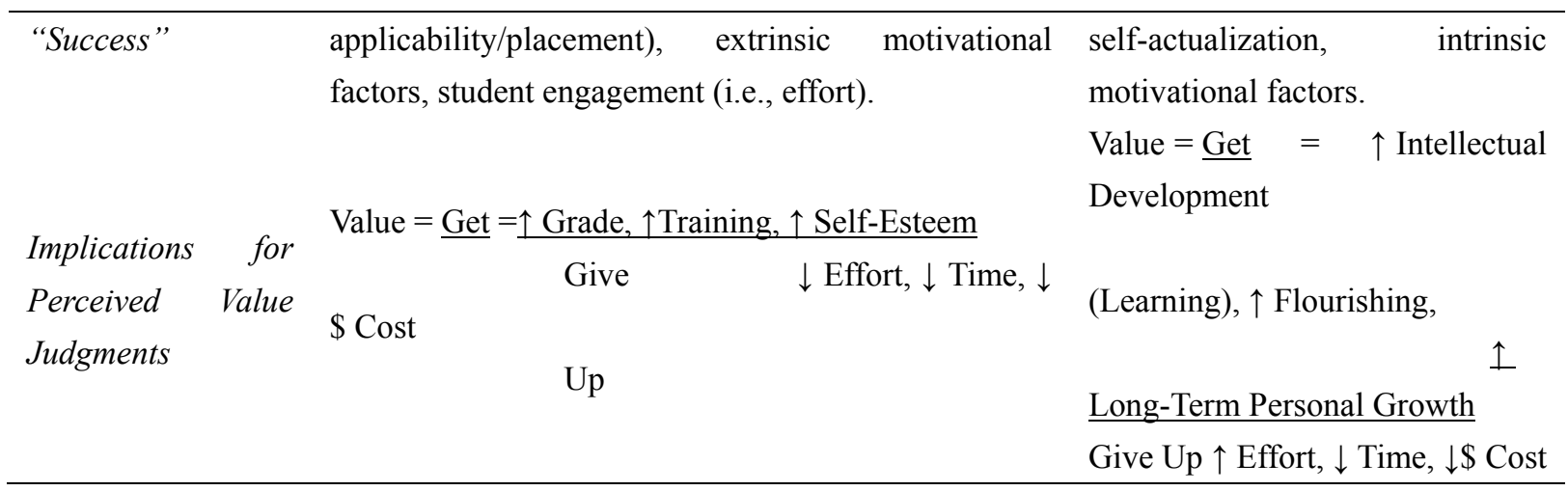

\section{Summary}

The emerging QOL literature identifies two general forms of happiness, each underlying a different form of satisfaction (see Table 4). An argument is made that today's typical marketization emphasis relates most closely to satisfaction as hedonia, whereas the QOL literature appears to be generally more supportive of eudaimonic forms of satisfaction as measures of life-related "success." Having identified varying forms of satisfaction, we now turn to the identification of which are appropriate measures for marketing success when viewed through the lens of the emerging marketing-related literatures related to SDL and stakeholder orientation. We ultimately conclude that both forms of satisfaction appear to be important components of marketing "success" with higher education.

\subsection{The Service Dominant Logic (SDL) and the Marketing of Higher Education}

The preceding review of the emerging QOL literature appears to generally support calls for emphasizing eudaimonic forms of satisfaction in addition to the hedonistic forms typically used today as part of marketization practices. Table 4 demonstrates how this affects typical attributes measures for "marketing success" and stakeholders' perceived value equations in higher education, consistent with Judson and Taylor's (2014) characterization of marketization versus marketing practices. This section explores this characterization in greater depth from the perspective of emerging marketing theory.

The crux of Judson and Taylor's (2014) argument is that typical marketization practices in higher education fail to recognize the evolution of service marketing thought and practices, particularly Vargo and Lusch's (2004) SDL theory for marketing that moves from a focus on (1) tangible resources, embedded value, and transactions to (2) a focus on intangible resources, the co-creation of value, and relationships. Vargo et al. (2008) argue that within the SDL perspective that value is fundamentally derived and determined in use (i.e., the integration and application of resources in a specific context) as opposed to in exchange (i.e., embedded in firm output and captured by price). These authors further suggest that moving the locus of value creation to use (or context) from exchange means transforming our understanding of value from one based on units of firms output to one based on processes that integrate resources. Judson and Taylor's (2014) call for embracing the SDL in marketing practices associated with higher education is consistent with similar calls from Ford and Bowen (2008) and Woodall et al. (2013). This leads to the fourteenth proposition:

P14: There is growing support within academic marketers of higher education supporting movement toward higher education marketing practices that are consistent with the SDL perspective of marketing.

Embracing the SDL perspective suggests a number of implications for the marketers of higher education, many of which we argue should complement today's traditional marketization practices (e.g., delivered educational value, hedonistic satisfaction measurement of "success", etc.). First, in SDL the emphasis in marketing management is on service systems, or arrangements of resources (including people, technology, information, etc.) connected to other systems by value propositions. A focus on service systems places the issues considered herein within the domain of service science, which is the study of service systems and the co-creation of value within complex constellations of integrated resources (Vargo et al., 2008). The delivery of higher education is already beginning to appreciate the changes implicit in a movement toward the SDL perspective. Baron and Harris (2006) suggest a movement in content/curricular emphasis from the role of goods toward an emphasis on consumer experiences based on the SDL. In addition, they also call for a far greater emphasis on the student as a consumer, and on the students' own experiences, through a network of personalized interactions. Typical marketization practices in higher education may prove to poorly reconcile with a a service science system perspective. That is, 
these authors argue that marketization models have potentially negative reinforcing potential, including an increased reliance on short-term job placement, student enrollments/revenues, and student evaluations as the primary basis of faculty performance evaluations, subsequent grade inflation, and the general transformation of education into a private good (commodity) as opposed to the original view of higher education as a public good. In fact, the reinforcing patterns of marketization practices may prove to not only fail to facilitate the co-creation of value, they arguably typically produce poor learning results even from the pre-SDL perspective of tangible resources, embedded value, and transactions (Arum \& Roska 2011). Moving away from the hedonistic attributes identified in Table 4 as the primary measures of marketing performance is arguably a necessary first step toward building an appropriate marketing managerial control system consistent with the SDL perspective. This leads to the fifthteenth proposition:

P15: Measures of marketing performance in the delivery of higher education should place greater weight on eudaimonic system-wide influences on student personal growth and flourishing, expressed as increased social capital, in addition to more immediate student and organizational marketing objectives (i.e., hedonistic measures such as engagement, job relevancy, enrollment indices).

Second, moving toward the SDL- and service science-based marketing perspective is supported by the evolving conceptualization and treatment of value in marketing generally, and toward higher educational services specifically. For example, Ledden and Kalafatis (2010) argue that a review of the literature supports the general conclusions that value is generally understood to be (1) subjective, (2) perceived by the customer rather than determined by the seller, and (3) and is formed by a trade-off between benefits and sacrifices. Ledden and Kalafatis (2010) further present empirical evidence that (1) value also has a temporal dimension, and (2) affect and cognitive influences can differentially impact value formation across time. These insights suggest that value creation/co-creation can be explained as a latent perception based on social psychological processes. This position reconciles with the previous discussions.

Vargo et al. (2008) similarly assert that the purpose of value in the old view was to increase firm wealth, but in the SDL view it is to increase adaptability, survivability, and system wellbeing through service (i.e., applied knowledge and skills) of others. How we measure perceived value now moves from price toward the adaptability and survivability of the beneficiary system. Thus, the role of the customer moves from the perspective of using up or destroying value toward value co-creation through the integration of firm-provided resources with other private and public resources. In summary, Vargo and Lusch (2004) assert that SDL focuses heavily on continuous processes wherein the consumer is always involved in the production of value (Note 3). That is, for service systems, value is defined in terms of improvement and environmental fit of a system's adaptiveness or ability to fit in its environment since the SDL perspective asserts that value is fundamentally derived and determined in use - not delivered through exchange (Vargo et al., 2008).

Helkkula et al. (2012) revisit the foundations of the value concept generally in marketing and conclude, consistent with the SDL perspective, that value in experience is the appropriate view of value co-creation. Specifically, Helkkula et al. (2012, p. 66) characterize value in the experience as “....an intrasubjective, socially intersubjective, context- and situation-specific phenomenon that is both lived and imaginary, constructed based on previous, current, and imaginary future experiences and is temporal." That said, Gronroos and Voima (2013) assert that a review of the service marketing literature makes clear that a consistent understanding of value and value co-creation has yet to emerge.

Woodall et al. (2013) further argue that perceived value and its relation to consumerist forms of satisfaction have now assumed substantial importance across nations. Unfortunately, these authors further identify that there is little agreement as how best to specify demand-side value, and that numerous concepts and theories prevail today. Vargo and Lusch (2008) assert that customer value within the SDL perspective is viewed as being idiosyncratic, experiential, contextual, and meaning-laden. Helkukula et al. (2012) extend this perspective to characterize the value-in-experience concept as an ongoing, iterative circular process of individual and collective customer sense-making, as opposed to a linear, cognitive process restricted to isolated service encounters. Taken together, perceived value from the SDL perspective involves an interactive, long-term, and subjective phenomenon (Helkukula et al., 2012) that represents a latent perception based on social psychological processes. This leads to the sixteenth proposition:

P16: The appropriate commensurable interpretation of the concept of perceived value associated with education should include both short-term, hedonistic perceptions of the perceived ratio of get/give up, as well as more eudaimonic definitions within the SDL framework focusing on longer term value co-creation, and derived based on social psychological processes. 
Third, care must be taken to not confuse the concepts of co-creation and co-production within the SDL framework. Etgar (2008) points out that the concepts of co-creation and co-production are related but not equivalent, concepts. Specifically, he argues that co-creation of value takes place through the value created in the consumption acts (i.e., during the usage/consumption stage), while co-production involve the core offering itself (usually preceding co-creation of value). This suggests several points: (1) co-creation and co-production are nested concepts with co-production being a subordinate concept to the co-creation of value; (2) co-production is an explicit result of decision-making by consumers reflecting their own preferences; and (3) co-production encompasses all cooperation formats between consumers and production partners. Etgar (2008) presents a five-stage model of co-production based on these arguments. This leads to the seventeenth proposition:

P17: The appropriate commensurable SDL-based interpretation of the concept of perceived value associated with education should consider both the co-creation of value, and the co-production of value processes, but not confuse them.

Fourth, a system perspective has relational implications for marketers of higher education. The SDL perspective is participatory and dynamic, therefore, service provision is maximized through an iterative learning process for both the consumer and the enterprise. In short, the SDL viewpoint assumes the existence of emergent relationships and evolving structures (e.g., relational norms of exchange learned through reinforcement over time), leading to the conclusion that the SDL is inherently both customer-centric and relational in value co-creation. This suggests that the appropriate commensurable SDL-based interpretation of the concept of perceived value associated with education should include longer-term measures of perceived performance. Such longer-term measures of "success" appear more consistent with eudaimonic forms of happiness. This leads to the eighteenth proposition:

P18: The appropriate commensurable SDL-based interpretation of the concept of perceived value in the marketing of education should reflect eudaimonic measures of happiness and SWB.

Fifth, satisfaction was previously identified as an appropriate measure of perceived happiness/SWB, with evidence from the QOL literature generally supporting eudaimonic forms of satisfaction. Ledden and Kalafatis (2010) argue that satisfaction mediates the perceived value formation $\rightarrow$ intention to recommend an educational institution relationship. Duque and Weeks (2010) propose a conceptual model for assessing student outcomes and satisfaction based on the emerging marketing literature. Their model, which focuses on perceived quality and satisfaction ratings as the main measures of service performance, posits that cognitive learning outcomes (defined as student acquisition of specific knowledge and skills) are exogenous to affective learning outcomes (defined as how much the university experience has impacted student's values, goals, attitudes, self-concepts, worldview, and behaviors) and satisfaction as a cumulative measure of the complete student experience, although they predict a relationship between educational quality (i.e., perceived excellence) and student satisfaction (Note 4). Their model does not include a hypothesized relationship between affective outcomes and satisfaction judgments. Woodall et al. (2013) similarly argues for the importance of satisfaction as an outcome measure of the marketing of higher education. Together, this suggests the important role of satisfaction judgments as an indicant of value co-creation within the SDL perspective. This leads to the nineteenth proposition:

P19: The appropriate constitutive and operational definition of satisfaction is an important indicant of stakeholder perceptions of "success" in terms of value co-creation and co-production associated with the delivery of higher education from the SDL perspective.

Satisfaction is constitutively defined within the marketing literature as the degree to which a consumer's fulfillment response is pleasant or unpleasant (Oliver, 2012), which is a function of expectancy disconfirmation. Expectancy disconfirmation involves the gap between one' view of marketing success (Perception) versus what is expected (Expectation), i.e., Perception-Expectation. Oliver (2012) argues that satisfaction general arises from affective appraisals and cognitive reasoning, both of which are based on individuals' goals. Mosokowitz (2012, p. 1) define goals as "A goal is an end state that the organism has not yet attained (and is focused toward attaining in the future) and that the organism is committed to approach or avoid." In this view, goals reside in memory as mental representations, with one source of goals being needs within the context of need satisfaction (Mosokowitz 2012). This perspective is consistent with both self-determination and expectancy-value theories. Mosokowitz (2012) asserts that the context determines what will become an individual's goal because certain actions are seen as more instrumental than others for the satisfaction of one's needs. The desirability, or perceived value, of the goal is at least in part determined by the association of the goal to a person's needs. Goals can therefore be viewed as standards or end states specifying something to attain or avoid, that an individual will 
try to bring about by initiating responding. Motivation is viewed as a function of expectancy and value of goals (Liberman and Forster 2012). Thus, goals are related to action through goal-striving (Sheeran and Webb 2012). This leads to the next two propositions:

P20: From a social psychological perspective, satisfaction judgments are related to value perceptions, goals, and motivation.

P21: Models designed to measure "marketing success" should include social psychological inquiries from a social psychological perspective leading to a better understanding of how stakeholder eudaimonic happiness and satisfaction judgments form vis-à-vis higher education, including the roles of value perceptions, goals, and motivation.

\section{Summary}

The SDL marketing theory appears consistent with the QOL literature in emphasizing (1) the importance of satisfaction as a measure of perceived "success" in marketing, and (2) eudaimonic forms of satisfaction better representing such success. Such eudaimonic satisfaction judgments derive from social psychological processes that must be incorporated into assessing marketing success consistent with both the QOL and SDL perspectives in the marketing of higher education. Marketing actions will benefit from social-psychological inquiries leading to a better understanding of the formation of eudaimonic forms of happiness and satisfaction. The next section now considers whether the emerging literature on stakeholder orientation similarly supports these conclusions.

\subsection{Stakeholder Orientation and the Marketing of Higher Education}

Arguably, one of the real tragedies of the synergistic forces of (1) calls for increased access to university education, and (2) shrinking support for treating education generally as a funded public good has been the increasing reliance on persuasive marketing communications to compete for qualified students each year. Privatization of higher education and associated marketization practices represent the inevitable outcome of such forces. The current paper will not enter the quagmire of this debate (Note 5), rather, will focus on marketing-related problems that have emerged. Primary among these problems is the problem of stakeholder relevance.

We suggest that a key marketing challenge that has resulted from these trends has been to make obscure which stakeholder set of goals should primarily drive the marketing actions of institutions of higher learning. Traditional marketization practices appear to emphasize students and employer stakeholder goals, primarily related to credentialing and training. In fact, a summary of the 2013 Gubernatorial State of the State Addresses for Higher Education reflect this conclusion (see http://congressweb.com/aascu/advisoryView.cfm?id=134784) makes clear the US nationwide impact of this orientation.

We find these trends very troubling from the perspectives of emerging marketing literature. First, such emphases fail to reconcile with Oliver's (2012) admonition to consider all relevant stakeholders (including the consumer, firm, industry, and societal perspective) where appropriate. We will ultimately argue for greater emphasis on the societal perspective within higher education. This argument is demonstrated in this section to be consistent with the emerging stakeholder marketing literature.

\subsection{The Emerging Stakeholder Marketing Literature}

Smith et al. (2010) identifies a new marketing myopia wherein marketers generally fail to recognize the broader societal context of business decision-making, instead choosing to focus on seeking to satisfy short-term, material needs through consumption behaviors. Bhattacharya (2010) similarly points out that traditional marketing strategy tends to be predominantly firm-centric, as in the case of marketization practices. Stewart (2010) argues that there has been a recognizable shift in stakeholder marketing research from a focus on regulation of the marketing function and its activities to a more balanced treatment of the reciprocity of marketing and society. We argue herein that the traditional marketization practices previously discussed herein typify this new form of marketing myopia.

Bhattacharya (2010) continues by arguing that the first step in value co-creation (consistent with the previously discussed SDL perspective) is a functional and psychosocial needs assessment of all relevant stakeholders, including the role of feedback in terms of stakeholder cognitions, attitudes, and behaviors central to the value co-creation process. He summarizes the emerging stakeholder marketing literature as encompassing some basic principles, including:

- Considering multiple stakeholder interests in developing, implementing, and evaluating marketing strategies; 
- Understanding the full impact of marketing on all stakeholders, including society and the environment;

- Studying relationships among stakeholders;

- Attempting to understand how best to effectively deal with commonalities and conflicts in stakeholder needs and interests; and

- Recognizing that these principles are not necessarily at odds with shareholder value maximization.

This leads to the next two propositions:

P22: Marketers for universities should seek to avoid the identified new form of marketing myopia and include the interests of all relevant stakeholders in strategy formulation, and particularly societies at large.

P23: Marketers for universities should include feedback loops between stakeholders' cognitions, attitudes, and behaviors in the strategies designed to co-create stakeholder value in marketing strategies.

The emerging literature in the stakeholder marketing domain can help clarify and inform university marketer strategies and tactics, as well as measures of "marketing success" from this perspective. For example, Ferrell et al. (2010) extend these arguments to recognizing that the marketing concept has been broadened beyond current customers and competitors to include future consumer and societal needs. These authors define the term "stakeholder" in this context as follows:

"An individual or group is considered a stakeholder of a business unit when ay of three characteristics applies: (1) when the actor has the potential to be positively or negatively affected by organizational activities and/or is concerned about the organization's impact on his or her or others' well-being, (2) when the actor can withdraw or grant resources needed for organizational activities, or (3) then the actor is valued by the organizational culture." (Ferrell et al., 2010, p. 94)

Table 5. Market orientation versus stakeholder orientation (Adapted from Ferrell et al., 2010 and Laczniak and Murphy 2012)

\begin{tabular}{|c|c|c|}
\hline & Market Orientation (MO) & Stakeholder Orientation (SO) \\
\hline Defir & $\begin{array}{l}\text { An organizational culture which provides norms } \\
\text { for behaviors that focus on assessing and acting } \\
\text { on customers' needs and anticipating and } \\
\text { responding to competitors' actions (Ferrell et al. } \\
2010 \text {, p. 94) }\end{array}$ & $\begin{array}{l}\text { The organizational culture and behaviors } \\
\text { that induce organizational members to be } \\
\text { continuously aware of and proactively act } \\
\text { on a variety of stakeholder issues. (Ferrell } \\
\text { et al. 2010, p. 93) }\end{array}$ \\
\hline $\begin{array}{l}\text { Typically } \\
\text { Involved } \\
\text { Stakeholders }\end{array}$ & Customers and competitors & $\begin{array}{l}\text { Customers, community, employees, } \\
\text { suppliers, investors, sustainability }\end{array}$ \\
\hline & $\begin{array}{l}\text { - Focuses on customers and competitors in } \\
\text { order to be more profitable. }\end{array}$ & $\begin{array}{l}\text { - Focuses on how organizations can } \\
\text { leverage their marketing expertise to } \\
\text { improve the welfare of all } \\
\text { stakeholders. }\end{array}$ \\
\hline of Focus & $\begin{array}{l}\text { - Focuses on competitiveness. } \\
\text { - Short-term competitive outcomes } \\
\text { important. }\end{array}$ & $\begin{array}{l}\text { - Dedicated to learning about and } \\
\text { addressing stakeholder issues. } \\
\text { - Interested in the long-term welfare of } \\
\text { all stakeholders. }\end{array}$ \\
\hline $\begin{array}{l}\text { Areas } \\
\text { Distinction }\end{array}$ & \multicolumn{2}{|c|}{$\begin{array}{l}\text { Ferrell et al. (2010) argue that MO identifies customers and competitors as the primary focus } \\
\text { (with little attention to the other stakeholder groups), whereas SO does not designate any } \\
\text { specific stakeholder group as more important than another - stakeholder prioritization occurs } \\
\text { depending on the issue at hand. }\end{array}$} \\
\hline
\end{tabular}




\begin{tabular}{lll}
\hline & Marketization & Marketing \\
Most Closely & Psychological Happiness & Prudential and Perfectionist Happiness \\
Associated & Short-Term Value Creation in the form of & Long-Term Value Co-Creation Consistent \\
& Fiscal/Operational Measures of Success & with the SDL Perspective \\
\hline
\end{tabular}

In support of their perspective, Ferrell et al. (2010) differentiate the concepts of marketing orientation from that of stakeholder orientation (see Table 5). A review of Table 5 makes clear that moving from a market orientation to a stakeholder orientation broadens the relevancy of more stakeholders, and often assumes a longer-term temporal orientation. We suggest that a focus on market orientation is precisely what marketers of higher learning are emphasizing in traditional marketing practices. Further, marketing's current movement toward a heavier emphasis on stakeholder orientation appears more consistent with both emerging trends in the (1) QOL literature toward eudaimonic forms of happiness/satisfaction as measures of success, and (2) value co-creation consistent with the SDL view of marketing practice. This leads to the next two propositions:

P24: Marketers of higher education should consider embracing the stakeholder orientation perspective instead on the market orientation typically associated with traditional marketization practices.

P25: Marketers of higher education should consider embracing Ferrell et al.'s (2010) definition of concept of stakeholder to help guide efforts to embrace a stakeholder orientation.

Laczniak and Murphy (2012) reinforce the perspectives advocated herein through their call for stronger forms of stakeholder marketing that reflect more normative, macro/societal, and network focused orientations as necessary (Note 6). They characterize their call as involving a "hard form" of stakeholder theory wherein marketing managers must realize that serving stakeholders sometimes requires sacrificing maximum profits in order to mitigate outcomes that would inflict major damage on other stakeholders, especially society. Like other proponents of a stakeholder orientation, Laczniak and Murphy (2012) assert that marketers have typically view consumers as commercial entities seeking to satisfy short-term, material needs through consumption behaviors i.e., are predominantly instrumental and company-centric (i.e., marketization). Importantly, the hard form of stakeholder theory understands the creation of value to be broader and more social than the typical customer/shareholder perspectives seen with marketization practices. These authors further associate the hard form of stakeholder theory as consistent with the SDL perspective given its understanding of the complex networks linking customer value to value of the firm for all its stakeholders. This leads to the next proposition:

P26: Marketers of higher education should consider embracing Laczniak and Murphy's (2012) hard form of stakeholder orientation in the development of marketing strategy development, implementation, and measures of success.

\section{Summary}

Consistent with our summaries of the QOL and SDL literatures, the emerging stakeholder orientation literature in marketing similarly appears consistent with the arguments of Judson and Taylor (2014) to move the marketing of higher education away from today's typical marketization practices, toward more evolved theory and practice. The next section summarizes the basic argument presented herein, and begins tackling the difficult issue of how marketers of higher education can begin to move in the directions more consistent with the emerging SDL pe5rspective of marketing, the emerging stakeholder orientation perspective of marketing, and the eudaimonic and flourishing oriented perspectives advocated by the emerging QOL literature.

Figure 1 summarizes the argument presented in this paper. In short, a review of three important emerging literature streams (i.e., QOL, SDL, and Stakeholder SO) all appear to support Judson and Taylor's (2014) call from moving beyond typical (short-term, hedonistic) measures of consumer satisfaction associated with the delivery of higher education toward satisfaction judgments based on higher-order forms of happiness (i.e., prudential and perfectionist forms of happiness such as eudaimonia). This conclusion appears consistent with assertions that the nature of long-term value associated with higher education should focus on quality of life and well-being. In addition, these authors note that perceptions of value either delivered or co-created will be based largely on stakeholder and organizational goal congruence. Judson and Taylor (2014) assert that the psychology underlying the progressive view of education is that the long-term perceived value of the educational experience should relate to development, and not the short-term value of the student's perceived immediate experience. Thus, the overarching marketing goal of institutions of higher learning should relate to enhancing human capabilities. Specifically, they call for consideration of long-term life satisfaction (i.e., eudaimonia and 
well-being) should be the top priority for institutions of higher learning seeking to protect the well-being of their students - and not short-term, hedonistic, consumer-related, psychological satisfaction. In other words, Judson

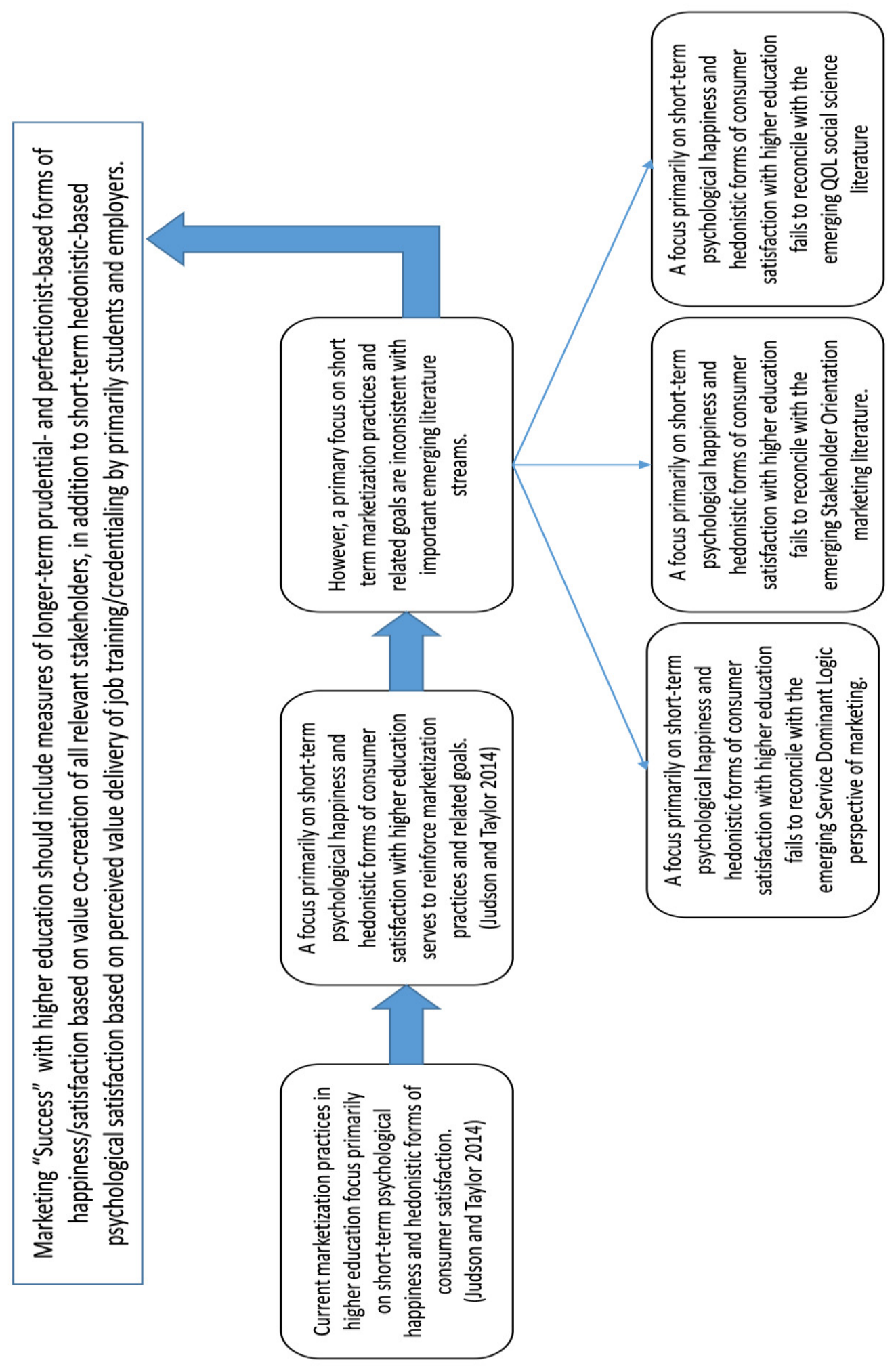

Figure 1. The Argument for Moving Toward Prudential- and Perfectionist -Based Measures of Marketing Success in Higher Education 
and Taylor (2014) assert that the collective goal of higher education for all stakeholders must be to educate for a lifetime, not simply train for an immediate job opportunity.

As noble as this call appears, it will be difficult to implement effectively in the absence of potential goal congruency among organizational stakeholders. Thus, the next proposition is as follows:

P27: Marketers of higher education should include goals related to their marketing strategies aimed at increasing the adoption of consistent stakeholder goals related to human flourishing and eudaimonia, not just job attainment and training.

Thus, in order to actually achieve Judson and Taylor's (2014) proposed model that focuses on four specific dimensions of marketing "success," including intellectual development, psychosocial changes, changes in attitudes and values, and moral development, a measure of goal consistency among all relevant organizational stakeholders must be achieved (Hofmann et al., 2013). Such goal consistency vis-à-vis longer-term eudaimonic forms of satisfaction will require marketers encourage stakeholders to rise above the impulse for immediate gratification by embracing a future-oriented mindset (Cheng et al., 2011). This will likely prove challenging, particularly for younger stakeholders (Steinberg et al., 2009). However, we assert that a key long-term strategic marketing objective for institutions of higher learning will be to affect increased stakeholder valuation of long-term, eudaimonic form of happiness instead of an almost singular focus on short-term, hedonistic forms of satisfaction as the basis for value perceptions. This leads to the final research hypothesis:

P28: Marketers of higher education should embrace the key long-term strategic marketing objective of affecting increased stakeholder valuation of long-term, eudaimonic forms of happiness rather than an almost singular focus on short-term, hedonistic forms of satisfaction as the basis for stakeholder goal congruence.

As a final thought, Alba and Williams (2013) review the body of knowledge related to hedonic consumption and similarly conclude that the concepts of flow and flourishing associated with eudaimonia appear achievable, even without an abundance of positive emotion, when accomplishment is the dominant form of flourishing. That is, activities can be emotionally satisfying and more motivating than material gain if imbued with meaning and a sense of progress. Thus, we are optimistic that the true marketing challenge of fostering the higher forms of satisfaction associated with eudaimonia and flourishing as the primary measure of marketing "success" with higher education is ultimately not beyond our reach.

\section{References}

Abbott, R. A., Ploubidis, G. B., Huppert, F. A., Kuh, D., \& Croudace, T. J. (2010). An Evaluation of the precision of measurement of Ryff's Psychological Well-Being Scales in a Population Sample. Social Indicators Research, 97, 357-373. http://dx.doi.org/10.1007/s11205-009-9506-x

Alba, J. W., \& Williams, E. F. (2013). Pleasure Principles: A Review of Research on Hedonic Consumption. Journal of Consumer Psychology, 23(1), 2-18. http://dx.doi.org/10.1016/j.jcps.2012.07.003

Arum, R., \& Roksa, J. (2011). Academically Adrift: Limited Learning on College Campuses. Chicago, IL: The University of Chicago press.

Baron, S., \& Harris, K. (2006). A New Dominant Logic in Marketing: Pedagogical Logic Implications. The Marketing Review, 6, 289-300.

Bhattacharya, C. B. (2010). Introduction to the Special Section on Stakeholder Marketing. Journal of Public Policy \& Marketing, 29(1), 1-3. http://dx.doi.org/10.1509/jppm.29.1.1

Chen, G. H. (2010). Validating the Orientation to Happiness Scale in a Chinese Sample of University Students. Social Indicators Research, 99, 431-442. http://dx.doi.org/10.1007/s11205-010-9590-y

Cheng, Y-Y., Shein, P P., \& Chiou, W-B. (2011). Escaping the Impulse to Immediate Gratification: The Prospect Concept Promotes a Future-Oriented Mindset, Prompting an Inclination Towards Delayed Gratification. British Journal of Psychology, 103, 129-141. http://dx.doi.org/10.1111/j.2044-8295.2011.02067.x

Csikszentmihalyi, M. (1997). Finding Flow: The Psychology of Engagement with Everyday Life. New York, NY: Basic Books.

Diener, E., Emmons, R. A., Larson, R. J., \& Griffin, S. (1985a). The Satisfaction with Life Scale. Journal of Personality Assessment, 49, 71-75. http://dx.doi.org/10.1207/s15327752jpa4901_13

Diener, E., Horwitz, F., \& Emmons, R. A. (1985b). Happiness of the Very Wealthy. Social Indicators Research, $16,263-274$. 
Diener, E., Wirtzx, D., Tov, W., Kim-Prieto, C., Choi, D., Oishi, S., \& Biswas-Diener, R. (2010). New Well-Being Measures: Short Scales to Assess Flourishing and Positive and Negative Feelings. Social Indicators Research, 97, 143-156.http://dx.doi.org/10.1007/s11205-009-9493-y

Dockray, S., Grant, N., Stone, A., Kahneman, D., Wardle, J., \& Steptoe, A. (2010). A Comparison of Affect Ratings Obtained with Ecological Monetary Assessment and the Say Reconstruction Method. Social Indicators Research, 99, 269-283. http://dx.doi.org/10.1007/s11205-010-9578-7

Duque, L. C., \& Weeks, J. R. (2010). Toward a Model and Methodology for Assessing Student Learning Outcomes and Satisfaction. Quality Assurance in Education, 18(2), 84-105. http://dx.doi.org/10.1108/09684881011035321

Etgar, M. (2008). A Descriptive Model of the Consumer Co-Production Process. Journal of the Academy of Marketing Science, 36, 97-108. http://dx.doi.org/10.1007/s11747-007-0061-1

Feinberg, W. (2012). I. Schooling, Inequity, and Commitment to the Public Good. Review of Research in Education, 36, 1-22.

Feldman, F. (2010). What Is This Thing Called Happiness? New York, NY: Oxford University Press.

Ferrell, O. C., Gonzalez-Padron, T. L., Hult, G. T. M., \& Maignan, I. (2010). From Market Orientation to Stakeholder Orientation. Journal of Public Policy \& Marketing, 29(1), 93-96. http://dx.doi.org/10.1509/jppm.29.1.93

Ford, R. C., \& Bowen, D. E. (2008). A Service-Dominant Logic for Management Education: It's Time. Academy of Management Learning \& Education, 7(2), 224-243. http://dx.doi.org/10.5465/AMLE.2008.32712620

Gronroos, C., \& Voima, P. (2012). Critical service logic: Making sense of value creation and co-creation. Journal of Academy of Marketing Science, 41(2), 133-150. http://dx.doi.org/10.1007/s11747-012-0308-3

Haybron, D. M. (2000). Two Philosophical Problems in the Study of Happiness. Journal of Happiness Studies, 1 , 207-225.

Helkkula, A., Kelleher, C., \& Pihlstrom, M. (2012). Characterizing Value as an Experience: Implications for Service Researchers and Managers. Journal of Service Research, 15(1), 59-75. http://dx.doi.org/10.1177/1094670511426897

Hofmann, W., Luhmann, M., Fisher, R. R., Vohs, K. D., \& Baumesiter, R. F. (2013). Yes, But Are They Happy? Effects of Trait Self-Control on Affective Well-Being and Life Satisfaction. Journal of Personality, 82(4), 265-277. http://dx.doi.org/10.1111/jopy.12050

Judson, K. M., \& Taylor, S. A. (2014). Moving from Marketization to Marketing of Higher Education: The Co-Creation of Value in Higher Education. Higher Education Studies, 4(1), 51-67. http://dx.doi.org/10.5539/hes.v4n1p51

Kahneman, D. (1999). Objective happiness. In D. Kahneman, E. Diener , \& N. Schwarz (Eds.), Well-being: Foundations of hedonic psychology (pp. 3-25). New York, NY: Russell Sage Foundation Press.

Kesebir, P., \& Diener, E. (2009). In Pursuit of Happiness: Empirical Answers to Philosophical Questions. In E. Diener (Ed), The Science of Well-Being: The Collected Works of Ed Diener (pp. 59-74). Dordrecht, Zuid-Holland: Springer.

Keyes, C. L. M. (2002). The Mental Health Continuum: From Languishing to Flourishing in Life. Journal of Health and Social Behavior, 43, 207-222. http://dx.doi.org/10.2307/3090197

Laczniak, G. R., \& Murphy, P. E. (2012). Stakeholder Theory and Marketing: Moving from a Firm-Centric to a Societal Perspective. Journal of Public Policy \& Marketing, 31(2), 284-292. http://dx.doi.org/10.1509/jppm.10.106

Ledden, L., \& Kalafatis, S. P. (2010). The Impact of Time on Perceptions of Educational Value. International Journal of Public Sector Management, 23(2), 141-157. http://dx.doi.org/10.1108/09513551011022492

Leon, J., \& Nunez, J. L. (2013). Causal ordering of Basic Psychological Needs and Well-Being. Social Indicators Research, 114, 243-253. http://dx.doi.org/10.1007/s11205-012-0143-4

Liberman, N., \& Forster, J. (2012). Goal Gradiants, Expectancy, and Value. In H. Aarts, \& A. J. Elliott (Eds.), Goal-Directed Behaviors (pp. 151-173). New York, NY: Psychology Press.

McGill, V. J. (1967). The Idea of Happiness. New York, NY: Springer. 
Moskowitz, G. B. (2012). The Representation and Regulation of Goals. In H. Aarts \& A. J. Elliott (Eds.),Goal-Directed Behaviors (1-47). New York NY: Psychology Press.

Myers, D. G., \& Deiner, E. (1996). The Pursuit of Happiness. Scientific American, 274, 70-72. http://dx.doi.org/10.1038/scientificamerican0596-70

Oliver, R. L. (1999). Value as Excellence in the Consumption Experience. In M. B. Holbrook (Ed.), Consumer Value (pp. 43-62). http://dx.doi.org/10.4324/9780203010679.ch2

Oliver, R. L. (2012). Satisfaction: A Behavioral Perspective on the Consumer, 2nd Edition. Armonk, NY: M. E. Sharpe.

Phillips, D. (2006). Quality of Life: Concept, Policy, and Practice. London: Routledge.

Raibley, J. R. (2013). Happiness is Not Well-Being. Journal of Happiness Studies, 13, 1105-1129. http://dx.doi.org/10.1007/s10902-011-9309-z

Sanjun, P. (2011). Affect Balance as Mediating Variable Between Effective Psychological Functioning and Satisfaction with Life. Journal of Happiness Studies, 12, 373-384. http://dx.doi.org/10.1007/s10902-010-9199-5

Sheeran, P., \& Webb, T. L. (2012). From Goals to Action. In H. Aarts, \& A. J. Elliott (Eds.), Goal-Directed Behaviors (pp. 175-202). New York, NY: Psychology Press.

Simsek, O. F. (2009). Happiness Revisited: Ontological Well-Being as a Theory-Based Construct of Subjective Well-Being. Journal of Happiness Studies, 10, 505-522. http://dx.doi.org/10.1007/s10902-008-9105-6

Sirgy, M. J. (2012a). The Exploration of Happiness: Present and Future Perspectives. In A. C. Michalos (Ed.), The Psychology of Quality of Life (2nd ed, pp. 3-14). New York, NY: Springer.

Sirgy, M. J. (2012b). The Psychology of Quality of Life, Second Edition. Social Indicators Research Series, 50, Alex C. Michalos (Ed.). New York: Springer.

Sirgy, M. J., Cole, D., Kosenko, R., Meadow, H. L., Rahtz, D., Cicic, M., ... Nagpal, N. (1995). Developing a Life Satisfaction Measure Based on Need Hierarchy Theory. In M. J. Sirgy \& A. C. Samli (Eds.), New Dimensions of Marketing and Quality of Life (pp. 3-26). Westport, CT: Greenwood Press,.

Smith, N. C., Drumwright, M. E., \& Gentile, M. C. (2010). The New Marketing Myopia. Journal of Public Policy \& Marketing, 29(1), 4-11. http://dx.doi.org/10.1509/jppm.29.1.4

Steger, M. F., Frazier, P., Oishi, S., \& Kaler, M. (2006). The Meaning in Life Questionnaire: Assessing the Presence and Search for Meaning in Life. Journal of Counseling Psychology, 53, 80-93. http://dx.doi.org/10.1037/0022-0167.53.1.80

Stein, J. 2013, May). Millennials: The Me Me Me Ganeration. Retrieved August 1, 2014, from $\mathrm{http} / / /$ www.prjohnsonenglish.org/uploads/5/3/8/5/5385246/millennials_themememegeneration.pdf, accessed 1/8/2014 .

Steinberg, L., Graham, S., O'Brian, L. Woolard, J., Cauffman, E., \& Banich, M. (2009). Age Differences in Future Orientation and Delay Discounting. Child Development, 80(1), 28-44. http://dx.doi.org/10.1111/j.1467-8624.2008.01244.x

Stewart, D. W. (2010). Reinventing Marketing and Public Policy for the Twenty-First Century: An Editorial Statement. Journal of Public Policy \& Marketing, 32(1), 1-5. http://dx.doi.org/10.1509/jppm.32.1.1

Sumner, L. W. (1996). Welfare, happiness, and ethics. New York, NY: Oxford University Press.

Taylor, S. A., \& Judson, K. (2011). A Service Perspective on the Marketization of Undergraduate Education. Service Science, 3(2),1-18. http://dx.doi.org/10.1287/serv.3.2.110

Taylor, S. A., Hunter, G., Melton, H., \& Stephen G. (2011). Student Engagement and Marketing Classes. Journal of Marketing Education, 33(1), 73-92.

Twenge, J. M., Campbell, W. K., \& Freeman, E. C. (2012). Generational Differences in Young Adults' Life Goals, Concern for Others, and Civic Orientation, 1966-2009. Journal of Personality and Social Psychology, 102(5), 1045-1062. http://dx.doi.org/10.1037/a0027408

Vargo, S. L., \& Lusch, R. F. (2004). Evolving to a New Dominant Logic for Marketing. Journal of Marketing, 68, $1-17$.

Vargo, S. L., \& Lusch, R. F. (2008). Service-Dominant Logic: Continuing the Evolution. Journal for the 
Academy of Marketing Science, 36(1), 1-10. http://dx.doi.org/10.1007/s11747-007-0069-6

Vargo, S. L., Maglio, P. P., \& Akaka, M. A. (2008). On Value and Value Co-Creation: A Service Systems and Service Logic Perspective. European Management Journal, 26, 145-152. http://dx.doi.org/10.1016/j.emj.2008.04.003

Veenhovern, R. (2000). The Four Qualities of Life. Journal of Happiness Studies, 1, 1-39.http://dx.doi.org/10.1023/A:1010072010360

Vitterso, J., Soholt, Y., Hetland, A., Thorsen, I. A., \& Roysamb, E. (2010). Was Hercules Happy? Some Answers from a Functional Model of Human Well-Being. Social Indicators Research, 95, 1-18. http://dx.doi.org/10.1007/s11205-009-9447-4

Woodall, T., Alex, H., \& Resnick, S. (2012). Making Sense of Higher Education: Students as Consumers and the Value of the University Experience. Studies in Higher Education. http://dx.doi.org/ 1080/03075079.2011.648373.

Yiengprugsawan, V., Seubsman, S., Khamman, S., Lim, L. L. Y., Sleight, A. C., \& the Thai Cohort Study Team (2010). Personal Well-Being index in a National Cohort of 87,134 Thai Adults. Social Indicators Research, 98, 201-215. http://dx.doi.org/10.1007/s11205-009-9542-6

Zeithaml, V. A. (1988). Consumer Perceptions of Price, Quality, and Value: A Means-End Model and Synthesis of Evidence. Journal of Marketing, 52, 2-22. http://dx.doi.org/10.2307/1251446

\section{Notes}

Note 1. Oliver (2012) further distinguishes four unique satisfaction response models vis-à-vis affective responses, including contentment, pleasure, delight, and relief. He argues that each of these satisfaction responses can be uniquely distinguished by the nature of associated cognitions, attribution, and emotions operating across the stages of consumption.

Note 2. Raibly (2013) distinguishes (1) attunement as involving peace of mind or tranquility and confidence, from (2) engagement which involves taking an active interest in the events of one's own life (characterized by flow, Csikzentmihalyi 1997), from (3) endorsement which involves positive emotions, especially joy and cheerfulness.

Note 3. Specifically, Vargo and Lusch (2004, p. 11) argue that “...the customer becomes primarily an operant resource (coproducer) rather than an operand resource ("target") and can be involved in the entire value and service chain in acting on operand resources."

Note 4. Interestingly, Taylor and Judson (2011) are unable to empirically validate this relationship with a cohort of business students.

Note 5. Interested readers are directed to Feinberg (2012) for a jumping off point in exploration of this debate.

Note 6. Laczniak and Murphy (2012, p. 287) describe the characteristics of their recommended hard-form of stakeholder theory as (1) normative and aspirational in terms of its ethical standards, (2) addresses questions about the conduct of marketing that are fundamentally macro in nature rather than form centric, and (3) prescribes greater engagement with external stakeholder networks rather than exclusively focusing on customer concerns within the exchange process.

\section{Copyrights}

Copyright for this article is retained by the author(s), with first publication rights granted to the journal.

This is an open-access article distributed under the terms and conditions of the Creative Commons Attribution license (http://creativecommons.org/licenses/by/3.0/). 